\title{
Isolated myocysticercosis: rare presentation in quadriceps muscle
}

\section{Ankit Bhardwaj ${ }^{1 *}$, Sangeeta Sharma ${ }^{1}$, Amit Arya ${ }^{1}$, Suman Kushwaha ${ }^{2}$, Monali Chaturvedi ${ }^{3}$}

${ }^{1}$ Department of Neuropsychopharmacology, ${ }^{2}$ Department of Neurology, ${ }^{3}$ Department of Radiology, IHBAS, Dilshad Garden, Delhi, India

Received: 10 December 2019

Accepted: 13 January 2020

*Correspondence:

Dr. Ankit Bhardwaj,

Email: drankitbhardwaj25@gmail.com

Copyright: (C) the author(s), publisher and licensee Medip Academy. This is an open-access article distributed under the terms of the Creative Commons Attribution Non-Commercial License, which permits unrestricted non-commercial use, distribution, and reproduction in any medium, provided the original work is properly cited.

\begin{abstract}
Myocysticercosis is not a common disorder and in particular quadriceps muscle is rarer. We are reporting this rare case of myocysticercosis involving quadriceps muscle of right thigh with ultrasonographic demonstration of nodular scolex and associated edema with no neurological involvement.
\end{abstract}

Keywords: Myocysticercosis, Cysticercosis, Quadriceps muscle, Taeniasis, Nodular scolex, Taenia solium

\section{INTRODUCTION}

Myocysticercosis a rare manifestation caused by larval form of the pork tapeworm, Taenia solium. The occurrence of larval cysts in humans in order of frequency is the central nervous system, vitreous humor of eye, striated muscle, subcutaneous tissues and rarely other tissues. Isolated muscular involvement is a rare and because of non-specific symptoms is difficult to diagnose. ${ }^{1}$ Till date handful of cases of muscular cysticercosis have been reported.

\section{CASE REPORT}

A 22-year old non-vegetarian female presented to neurology OPD of IHBAS, with complaints of swelling and pain in lateral aspect of right thigh. Swelling was initially a size of almond and moving medial and laterally with movements of legs. Positive history of pork consumption five year back. No present history of epilepsy, trauma and sensory or motor deficit of her involved leg. On examination swelling $33 \times 25 \mathrm{~mm}$ with erythema on overlying skin was found. Swelling was soft in consistency, tender with slight raised temperature. The surface was smooth, margins were ill defined and fluid thrill was absent. Swelling was fixed to underlying structures but overlying skin was freely movable. Sonography of thigh was suggestive of a cystic lesion of size $23 \times 6 \mathrm{~mm}$ in lateral compartment of thigh with nodular scolex and surrounding edema suggestive of myocysticercosis (Figure 1 and 2). Other visualized structures show normal echo texture. Patient responded to four weeks albendazole and prednisolone treatment. No surgical intervention was done. Repeat ultrasound after one month showed reduction in edema in surrounding tissue.

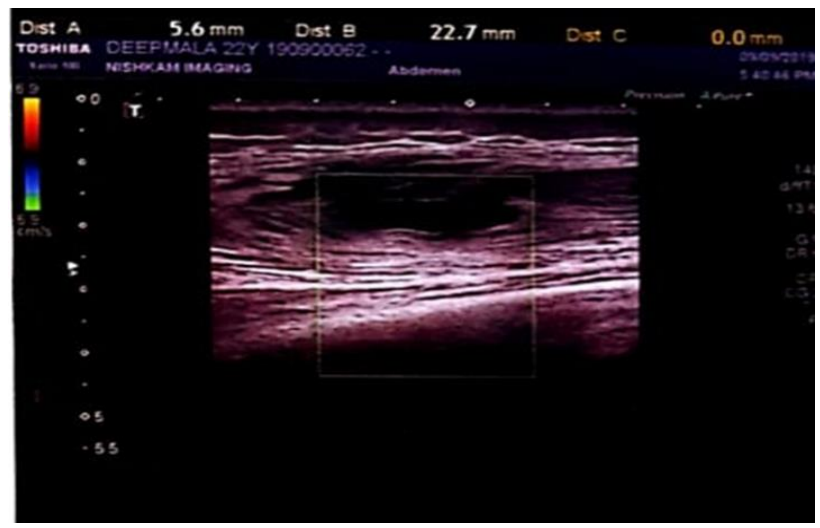

Figure 1: High resolution ultrasonography showing nodular scolex with surrounding edema. 


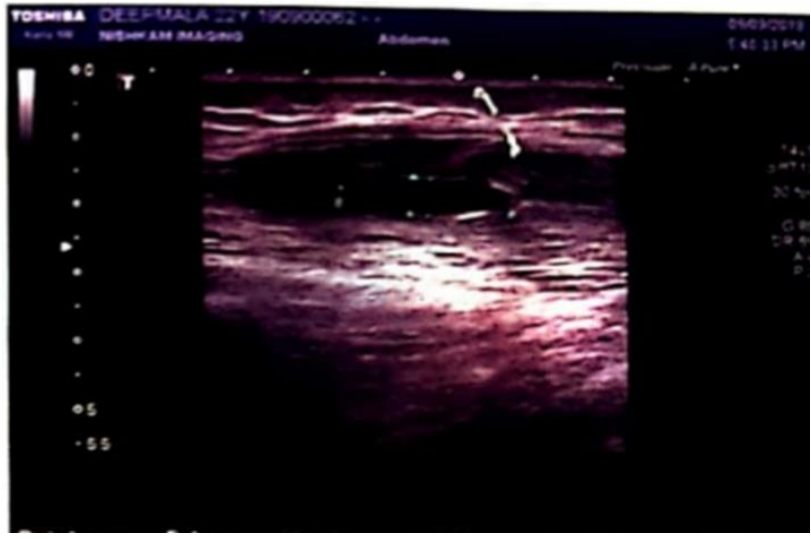

Figure 2: Demonstration of the associated surrounding edema.

\section{DISCUSSION}

Helminthes $T$. solium larval form can infest in any tissue of the body and cause cysticercosis in human. Poor hygiene, pork consumption, poor pork husbandry practice are risk factors associated with cysticercosis. Tapeworm infestation can be seen in two different presentation based on stage of life cycle, adult tapeworms in the intestine (Taeniasis) or with larval forms in the tissues (cysticercus cellulosae). ${ }^{1}$ Pigs are intermediate host while humans are the only definitive hosts for $T$. solium.

Cysticercosis can affect various organs including, the brain, spinal cord, orbit, muscle, subcutaneous tissue and even heart. Clinical manifestations depends upon anatomic sites of larval encystment, number of cysts and associated inflammatory response or scarring. ${ }^{2}$ Soft tissue cysticercosis frequently presents with multiple intramuscular lesions and central nervous involvement. Isolated soft tissue involvement is rare and clinically can be confused with other soft tissue lesions like neoplasm, lipoma, sebaceous cyst, neurofibroma and other inflammatory pathologies. ${ }^{3}$ Serological test for specific anti-cysticercal antibodies as also reported by Singh et al has low sensitivity when the parasite burden is low as in solitary lesion. ${ }^{4}$ High frequency ultrasonography is the most reliable diagnostic modality for soft tissue swelling. ${ }^{5}$ Imaging methods CT and ultrasonography (USG) are equally effective in identifying the cyst and the scolex. ${ }^{6}$ Three types of USG presentation can be there: ${ }^{7}$

- Cyst with scolex without surrounding edema (most common).

- Cyst with scolex and surrounding edema (as in the present case).

- Irregular cyst with no scolex and with surrounding edema (least common).

Surgical excision is preferred treatment modality for the cysticercosis with abscess but in the present case, there was no abscess formation, responded to anthelminthic albendazole with prednisolone and follow up USG done after 4 weeks of treatment showed marked resolution of edema (Figure 2).

\section{CONCLUSION}

Myocysticercosis is a not so common manifestation but involvement of isolated muscle (quadriceps muscle in the present case) is a rare presentation. In a developing country like India it should always be kept as differential diagnosis for solitary lump and subcutaneous and intramuscular swellings. USG is an inexpensive, easily available tool for diagnosis of myocysticercosis. When myocysticercosis is confirmed, neurocysticercosis should be ruled out by brain imaging. Measures for prevention of the diseases by proper cooking of meat, proper sanitation and hygiene practices and boiled and clean drinking water habits should be emphasized. Early diagnosis and treatment of myocysticercosis is always beneficial.

\section{Funding: No funding sources \\ Conflict of interest: None declared \\ Ethical approval: Not required}

\section{REFERENCES}

1. Prasad KN, Prasad A, Verma A, Singh AK. Human cysticercosis and Indian scenario: a review. J Biosci. 2008;33(4):571-82.

2. Rangdal SS, Prabhakar S, Dhat SS, Prakash M, Dhillon MS. Isolated Muscle Cysticercosis: A rare Pseudotumur and diagnostic chalengel,can it be treated Nonoperatively? A report of two cases and review of literature. J Postgrad Med Edu Res 2012;46:43-8.

3. Gupta MK, Ahmad K, Ansari S, Rauniar RK, Chaudary S. Isolated Cysticercosis of Anterior Abdominal wall mimicking clinically as acute appendicitis: An unusual presentation. J Universal College Med Sci. 2013;1:45-7.

4. Singh S, Singh AK, Sharma NK, Pandey A. Solitary myocysticercosis of masseter muscle: A rare presentation. Natl J Maxillofac Surg 2018;9:229-31.

5. Smiti S, Sripathi H, Naik L. Unusual location of cysticercus lesions in soft tissue - report of three cases. Indian J Radiol Imaging. 2003;13:157-8.

6. Kraft R. Cysticercosis: an emerging parasitic disease. Am Fam Physician. 2007;76:91-6.

7. Naik D, Srinath MG, Kumar A. Soft tissue cysticercosis ultrasonographic spectrum of the disease. Indian J Radiol Imaging. 2011;21:60-2.

Cite this article as: Bhardwaj A, Sharma S, Arya A, Kushwaha S, Chaturvedi M. Isolated myocysticercosis: rare presentation in quadriceps muscle. Int J Basic Clin Pharmacol 2020;9:361-2. 